Brazilian Journal of Political Economy, vol. 40, $n^{\circ}$ 2, pp. 332-354, April-June/2020

\title{
“Developmentalist Brazil” (1945-1964) as a concept: historicizing and (re)periodizing development in Brazil
}

\author{
"Brasil Desenvolvimentista" (1945-1964) como conceito: \\ historicizando e (re)periodizando o desenvolvimento no Brasil
}

ALEXANDRE DE FREITAS BARBOSA*,***

RESUMO: O artigo apresenta uma periodização alternativa do debate e prática de desenvolvimento no Brasil. Na primeira parte, é realizada uma recuperação da trajetória de Rômulo Almeida. O texto aponta como, durante o segundo governo Vargas, um grupo de burocratas cunhados como "intelectuais orgânicos do Estado" - passa a ocupar uma nova posição social. À medida que o processo de industrialização avança, surgem novas contradições, junto com outras posições sociais. Na segunda parte, novas categorias são construídas para identificar as diferentes concepções de desenvolvimento durante o período 1945-1964. Em seguida, depois de realizar uma reconstituição dos vários usos do "desenvolvimentismo" ao longo da história do Brasil, o texto aprofunda o conceito de "Brasil Desenvolvimentista", com o intuito de capturar a dinâmica interna do período. O objetivo é integrar ideias e posições sociais, de um lado, e processos estruturais, de outro, de modo a confrontar as estratégias de desenvolvimento. $\mathrm{O}$ período "pós-desenvolvimentista" (1964-1980) é caracterizado como uma ruptura na sua tentativa de lançar um novo padrão de desenvolvimento para superar as crescentes contradições vividas durante o "Brasil Desenvolvimentista" (1945-1964). Ao final, é esboçado um programa de pesquisa que poderia auxiliar na compreensão das transformações estruturais ocorridas no Brasil no contexto da nova economia-mundo capitalista pós-1980

PALAVRAS-CHAVE: Desenvolvimento; desenvolvimentismo; intelectuais; nacionalistas; Estado; industrialização; pensamento econômico.

ABSTRACT: The paper presents an alternative periodization of the debate and practice of development in Brazil. It starts with a brief depiction of Rômulo Almeida's trajectory. It states that during the second Vargas government, a group of bureaucrats - coined as "State organic intellectuals" - occupy a new social position. As the process of economic development unfolds, new contradictions arise, so as other social positions. In the second part, new

\footnotetext{
* Professor of Economic History and Brazilian Economy at the Instituto de Estudo Brasileiros da Universidade de São Paulo - IEB/USP, São Paulo/SP, Brasil. E-mail: afbarbosa@usp.br. Orcid:. https://orcid. org/0000-0002-0493-7488.

* Paper presented to the 4th Workshop on New Developmentalism of Fundação Getulio Vargas “Theory and Policy for Developing Countries”, São Paulo, 25-26 July 2019. Submitted: 25/July/2019; Approved: 1/August/2019.
} 
categories are constructed in order to describe the different conceptions of development during the period 1945-1964. Then, after presenting the many uses of the concept of "developmentalism" over history, the paper delves into the concept of "Developmentalist Brazil" in order to get into the inner dynamic of the period. The purpose is to integrate ideas and social positions, on the one hand, and structural processes, on the other, by addressing the conflicts over development strategies. The "Post-Developmentalist" period (1964-1980) is characterized as a rupture in its attempt to put in place a new development pattern to solve the rising contradictions faced during the "Developmentalist Brazil" period (1945-1964). At the end, we put forth a research programme that could possibly lead to the understanding of Brazil's structural changes in the context of the post-1980 new capitalist world-economy.

KEYWORDS: Development; developmentalism; intellectuals; nationalists; State; industrialization; economic thought.

JEL Classification: B-25.

\section{INTRODUCTION}

The purpose of this paper is to summarize some core ideas of my thesis submitted to the Chair of Economic History of Brazil at IEB/USP in November 2017. In the first part, it follows the trajectory of Rômulo Almeida, a State organic intellectual who occupied strategic positions in the country's economic bureaucracy during the period.

Secondly, the paper explores the development debate and practice in Brazil by formulating new categories that prioritize the social positions occupied by intellectuals and technicians. The aim is to investigate how these social positions and their respective ideas evolved from 1945 and 1964.

In the third part, after reconciling the many uses of the concept of "developmentalism" over history, the paper presents the alternative concept of "Developmentalist Brazil" coined for this period. By looking at the intersection of structural processes and the ideas the different kinds of intellectuals and technicians shared and fighter for - which mirrored wider conflicts -, the debate on and the process of development are integrated.

At the end, some general lines for an alternative periodization of capitalist development in Brazil in the long term are sketched and a final question addressed: what are the main conditions if we aim at rejuvenating a developmentalist perspective in order to face the challenges Brazil as a society is confronted to in the years to come. A project-interpretation-utopia, such as the one that arose during the "Developmentalist Brazil" but could not overcome its mains contradictions, is still possible?

Thus, the paper goes beyond the realm of economics, as it assumes the economics is a means (a very important one, indeed) and not and end in itself. In order to come up with a new set of (not only economic) development policies, we should ask whether they are desirable, viable and achievable in the society (Brazil) and in the world we live today. 


\section{RÔMULO ALMEIDA'S TRAJECTORY \\ AND THE STATE ORGANIC INTELLECTUALS}

Rômulo Almeida is a character almost unknown to most of Brazilian economic history and thought. Even though he has a place in the works of Draibe (1985), Bielschowsky (1995), Sola (1998) and Loureiro (1997) ${ }^{1}$ - authors who brought new depth to the debate and practice of development by looking at its unfolding in the fifties and sixties - its role within the State apparatus has not been investigated in depth. In this section, our aim is to stress the social position Almeida occupied in the State - then at the front stage -, and how he and the other "civic bohemians" 2 addressed the challenges faced by industrialization in the making.

Almeida graduated from the law school in Salvador in 1933 and moved to Rio de Janeiro in the following year. There, he worked as casual professor, journalist and held short term positions at the State through personal connections. He joined the "integralist" group - the quasi-fascist movement in Brazil - and was imprisoned after the 1937 coup d'état. In 1940, he moved up to the North of the country, helping to organize the 1940 Census. By 1942, he was back to Rio de Janeiro and worked with San Tiago Dantas in a law company providing consulting to private companies. Almeida was selected by DASP (Administrative Department of Public Sector) in 1944, which was the entrance gate to public service in Brazil. As a technical assistant of the Ministry of Labour, Industry and Trade - he produced a working paper evaluating a proposal of Roberto Simonsen to create an Economic Planning Comission. By the end of the decade, he had become the director of the Economic Division of CNI (Industrial National Confederation - the main body representing the businessmen of the industrial sector), which at the time played also the role of an advisory board to government for economic issues.

Before the election of Getulio Vargas (1951-1954), he was already well connected in the Brazilian public administration, having developed a complex understanding of the role of the State not only for unleashing the industrialization, as, according to his view, it needed to be balanced in social, regional and sectoral terms. In his letter of affiliation to PTB - which was a sort of a labour Brazilian party, even though very influenced by personal and clientelistic methods - he states some of his ideas concerning a development project that should move the country towards "economic emancipation" and "social progress".

In his own words, "apart from popular support - meaning workers and low

\footnotetext{
${ }^{1}$ Most of these works were conceived as $\mathrm{PhD}$ theses in the eighties and mark a turning point in the literature of development in Brazil. Apart from their peculiarities, they sought to establish some sort of connection between the "material world" and "the world of ideas". The notion that development has a double character in these intertwined worlds was developed by Fonseca (2014).

2 This is how President Vargas kindly labeled his closest advisors working at the Economic Advisory Board, as presented with more detail further in the article.
} 
middle class - this project needs to bring together the progressive sectors of the bourgeoisie and the high middle classes, in order to achieve social and economic efficiency" (Almeida, 1950, August, p. 1).

If this was the purported political coalition he had in mind, in the content of his "programme", there were administrative, fiscal and banking reforms, in order to launch productive investments, both private and public, that would increase employment levels. In the social arena, he pointed out the need to increase education spending and assure access of the different ranks of the population to all school levels, in order to do away with artificial barriers of race and class origin. A fair agrarian reform, with corresponding credit and technical assistance, was crucial to promote development and overcome underemployment. Wages needed to be pegged to national productivity. The Sate reform should comprise a new federalism without compromising the central government leadership in basic areas (Almeida, 1950, August, p. 3-6).

In February 1951, just after president Vargas took office, he was appointed to coordinate the writing of the message to the Congress, a task he had one month to accomplish. Then he became the head of the recently created Economic Advisory Board of the presidency. Almeida benefited from a network of around fifty public servants working in different fields, most of them selected by DASP, the administrative body of the public sector created in 1938, in charge of elaborating the federal budget and providing technical assistance to the central government (Barbosa, 2017, p. 164-165). According to Bielschowsky (1995, p. 339), this document is the first holistic attempt to ascertain the role of an integral industrialization as a means for the development of the country.

Actually, it was more than that. A close reading of the document shows that - if the role of consumption and capital goods industries deserves a great deal of attention, and also the role of external trade and foreign investment as tools to amplify the internal product, the nationalist mindset was unequivocal. Moreover, it welcomed the "new diplomacy" preaching for cooperation towards development, in which no colonialism is accepted, and a very clear-cut view on the need to avoid an "insensitive distribution" that could compromise the capitalization potential (Vargas, 1951, p. 12-13, 18-22, 99-100).

A substantial part of the message is devoted to the components of what is labeled "social progress", including public health, education, social security, labor and housing. The main tenets of a social welfare system, still embryonic, were then formulated by this elite of public servants

So, neither the document proposed an autarkic development, nor it envisioned the industrialization as an end in itself as portrayed by part of the literature produced by orthodox and even heterodox economists (Barbosa, 2017, p. 166-169).

The strategic role of the Economic Advisory Board of the presidency as the main producer of new institutions, laws and policies has also not been acknowledged by most of the historiographical literature devoted to the second Vargas government (1951-1954). One of the few exceptions is the work of D’Araújo (1992, p. 152-155). 
We can find working with Rômulo Almeida at the Economic Advisory Board other "on the job" economists like Jesus Soares Pereira, Ignácio Rangel, Cleanto de Paiva Leite and Tomás Pompeu Acioly Borges, most of them holding a degree in $\mathrm{law}^{3}$, and all of them born in the Northeast, the poorest part of the country. The same region of birth meant more than a geographic identity, but a common origin of class (low middle class with no job perspectives in their home states). These Northeastern "public servants" - a label all of them were proud of - sought to take part in the process of change that would be ignited at the core of the country and bring about new opportunities to other sectors of this still predominantly rural society and also to the more backward areas they came from.

At the Economic Advisory Board, they performed different tasks. First, they advised the president in issues related to the short-term economic management, presenting reports on the different issues raised by the ministerial bodies. Secondly, and most important, they envisioned a sort of "informal planning" in order to attack in a coordinated fashion the mains bottlenecks, not only in infrastructure, but also in terms of regional and social policies.

A collection of testimonies from Almeida and his fellows suggest that their personal bonds nurtured within the State apparatus helped to create a sense of mission amongst these nationalist technicians. Almeida was very fond of using words such as "cooptation" and "conspiracy", which he inverted the usual clientelistic meaning. To co-opt cadres of the State machinery and to organize an advisory conspiracy against the traditional oligarchic interests was see as a strategy for gathering new forces to support "their" nationalist project. They usually worked behind closed doors, leaving the big politics to president Vargas who sought to build an alliance with the most important parties (mostly from the right) in order to have a majority of the votes in Congress. The sign he gave to his close advisors enlisted to elaborate a project for the future State oil company, Petrobras, was the following: "a nationalist project but operational" (Barbosa, 2017, p. 173-175, 575-577).

Moreover, they knew the needed to establish stronger links with the society, including social movements, the middle-class technicians and the private sector. They had room for maneuvering, delegated by the president, even for changing projects sent by the different ministerial bodies. This was the case in the foreign policy, economic policy, infrastructure projects and regional and social policies as well, even though they did not win all the internal battles.

A question than arises: how can we describe these public servants that were project-oriented, had an interpretation of the bottlenecks (not only economic, but also political and social) faced by the country and also had a vision of development as a means for devising a modern nation in the tropics. This project-interpretationutopia, born in the core of the State apparatus, and aiming at building strong links

\footnotetext{
${ }^{3}$ Acioly Borges was an engineer and Soares Pereira a social scientist.
} 
with the dynamic and overarching society, is the basis for labeling them as State organic intellectuals.

Surely, they were not traditional intellectuals. Most of them, like Almeida, did not have time and ambition to produce such a thing as a knowledge enveloped in the form of an essay or a book. They could be depicted as "intellectuals in action", not "in habit", according to one of them ${ }^{4}$, acting within the entrails of the system and projecting its change motivated by their own interpretation of this society. Positivism and modernism were sources they draw upon but mixing them with self-taught knowledge in economics and sociology and creating a new vision of how to overcome the very peculiar and hard to change underdeveloped structures.

In the case of Almeida, we followed this new mindset from his writings in economics, history, geography and political institutions in the forties and fifties, not in an academic fashion, but as someone who had always put himself in the position of a bureaucrat bringing real changes to the society. In the working paper he produced just after the launch of Simonsen's planning document, the following statement is very significant for our purpose: "planning should not be seen only as an administrative style, but as a means to mobilize society for the future of the country" and to "educate Brazilian democracy for a safe working". Finally, "the plan is not the domain of a technocracy, but a social and economic technology on behalf of politics", here more in the sense of policy (Almeida apud Barbosa, 2017, p. 69-72).

If there was a naïve view of the State as an epiphenomenon to societal clashes and conflicts, in which there is always room for maneuvering and reaching provisory consensus, one should not downplay this view as "ideological" in the negative sense.

The State organic intellectual is therefore an analogy to the Gramscian conceptual framework for a reality, the Brazilian one, not easily manageable by the Italian Marxist toolkit. If the bohemian civics were not "traditional intellectuals" in the sense that they did not seek to preserve the economic structure being dismantled; they also cannot be considered as representatives of the fundamental economic classes of typical capitalist society, that is, the proletariat and the bourgeoisie (Gramsci, 2001, p. 15-25).

However, they acted, within the State (the political society) as both specialists and political directors of the industrialization process, aiming at a "cultural and moral reform" in the sphere of the superstructure by reaching other sectors of the civil society. By doing so, they intended to establish an organic bond with the fastchanging infrastructure. The "war of positions", in this case, takes place both at the State and the civil society, with the predominance of the former. The "party will" which Gramsci associates with the "State will" - anchored in a shared collective project - can be found in the social position occupied by these and many other

\footnotetext{
${ }^{4}$ See the interview of Guerreiro Ramos, a sociologist working with the Economic Advisory Board in Oliveira (1995, p. 167).
} 
intellectuals (not only economists) placed within the State, although they were far from hegemonic (Gramsci, 2017, p. 16-19, 35-37, 40-42, 88-89, 247-248, 266) .

It would be idealistic, if not biased, to pretend these attitudes were representative of the whole bureaucracy in Brazil. On the contrary, Almeida, for instance, was pretty much influenced by the analysis of Jaguaribe pointing out the need of overcoming the "clientlelistic State" as the only way to implement full democracy. An "ideological politics", based in projects and visions should fill the scene and allow for a transparent dispute of social and political interests (Jaguaribe, 1958, p. 21-31).

Notwithstanding that, there is a whole tradition of studies on the nature of the Brazilian State which underestimate the heterogeneity of interests, social positions and attitudes within the Brazilian bureaucracy in the period 1930-1964, as if a new dynamic had not arisen, settling the contradictions at a different and higher plateau, especially after 1945 . The very idea of a "bureaucratic stratum" resistant to any change most often than not has become a way to close any further discussion.

Some few examples deserve mentioning. For instance, Miceli (1992, p. 76-77, $115-120,197-199,376-377)$ states that the heavy net of the political sphere invaded the precarious intellectual sphere, devoid of purposeful agency apart from personal interests. The story goes like this: in the context of "inflation of diplomas" and scarcity of jobs in the private sector, after the thirties the heirs of the decadent oligarchy were taken care of by the authoritarian State. In exchange, they gave away their autonomy. No analysis is developed on how they worked within the State. The equation seems to invalidate any frictions. The social position acquired is the only argument to sustain the whole argument, as if the ideas and utopias they held were mere ornaments.

This view is also supported by Lafer (2002, p. 35, 67 e 70), whom at least acknowledges that this cooptation in the traditional sense went hand in hand with the new needs of a public administration that was about to play different roles and face different requirements from the society.

A more nuanced interpretation is found in Martins (1976, p. 230-240). However, the author does not see any rupture between the Corporatist State (1930$1945)$ and the Populist State (1945-1964) - according to his labelling of these periods - as the State is still a field restricted to the "elites", some of which trying to reach out to the "masses" in order to benefits themselves.

Other authors perceive not only a transformation within the State structure due to the rise of middle class groups, weakening its oligarchic nature (Ianni, 1971, p. 18-22), but also acknowledge the assets these new intellectuals were able to provide: "the scientific knowledge of the social" (Pécaut, 1990, p. 20-22, 30-33, 59). Summing up, the technical and scientific knowledge they possessed brought about new dynamics to the structural transformation process, thus directly affecting the way policies were shaped and implemented (Cunha, 1963, p. 6-7).

\footnotetext{
${ }^{5}$ In this paragraph, many of the Gramsciam categories were used in other to make them operational to understand these intellectuals and how they operated in the period 1946-1964.
} 


\section{THE DEBATE ON DEVELOPMENT AND ITS PRACTICE: IN SEARCH OF NEW CATEGORIES}

A reader of this article might argue that this is not about economics. Before you stop reading, let us try to make a point: in the late-comer countries of the $20^{\text {th }}$ century - in which capitalism took time to arise from within, spreading its dynamics in order to reach and conquer different groups of society -, the field of economics was most often than not intertwined with other fields of science and arts, all of which assumed a marked political dimension. There was a merging of the sphere of the culture in its broader sense with the nation building process. The fields did not exist as such so undifferentiated they were (Pécaut, p. 7, 18 e 89; Brandão, 2007, p. 22).

In the case of economics, some peculiarities deserve mentioning: first, it was mostly structured around the State; secondly, its first debate was held by two engineers - Roberto Simonsen and Eugenio Gudin in 1944 and 1945; finally, even though the contenders had their own understanding of the economics rationale, and were attuned to the trends of Western economic theories of the time, they filtered them in order to provide direction for social and political actors.

The industrialist Roberto Simonsen wrote his piece on "the planning of Brazilian economy", upon a request of the Minister of Labour, Industry and Trade. Planning, industrialization and the empowerment of the national economy were part of the seme equation. In a very ecletic way, Simonsen managed to combine proteccionism, the need of foreign capital and equipment and the role of the State, due to the low capacity of the private nacional capital as an engine to promote growth, increase productivity and create new jobs (Simonsen, [1944], 2010, p. 39-41, 4447). Nation and market were seen as two sides of the same token. This is the reason Bielschowsky (1995, p. 81-82) coined Simonsen the "pioneer developmentalist".

Gudin ([1945] 2010, p. 87, 90-93, 109) replied by arguing that "no plan was possible without monetary estability". Capital was scarce and required freedom of choice to make the best use of the available opportunities in order to increase productivity.

In sum, whereas Simonsen saw no possible alternative for increasing productivity if not led by industrial development, Gudin understood productivity as dependant on the availability of the factors of production and comparative advantages of Brazil, so any further industrial development should be prompted by foreign capital flows.

The main terms of this foundational debate of the Brazilian political economy would be somewhat reshuffled in the 1950s. Now, two groups of State technicians - the nationalists and the market leds - sought to specify the role of the State in the process of economic development.

The group of nationalists was located at the Economic Advisory Board as presented above. The other group of market led technicians was settled with the creation of Brazil/United States Joint Comission in March 1951. Lucas Lopes, Roberto Campos and Glycon de Paiva were the leading figures of this group, which 
later played a key role under Juscelino Kubitschek (JK) government (1956-1960). They were known as the "three musketeers" (Campos, 1994, p. 207-208, 293).

While the first group devised the new State bodies in order to expand infrastructure, the second was dedicated to formulate the projects that eventually would be financed by the World Bank and the EximBank. Although both groups worked together, pushing for the creation of BNDE (National Bank of Economic Development) in 1952, they had different visions about the means and ends of the development process under way.

That's why it is so crucial to acknowledge their social positions and the way they acted within the State bureaucracy, which has no resemblence with the post-1964 new character, the technocrat. Sola $(1998$, p. 152) took from an interview with Celso Furtado the best category, in our view, to define these two group of economists nothwistanding their different ideologies: "technicians ins ends".

Our attempt here is to contribute to the debate on development in Brazil during the period 1945-1964 by discussing how the main actors and currents of thought have been described in the literature in order to propose a new classification and set of categories.

Bielschowsky $(1995$, p. 33-35, 103) locates the places in which the ideas were formulated as a key component of the whole picture. Apart from the "private sector developmentalists", he breaks down the "public sector developmentalists" in two groups: nationalists and "non nationalists", the latter "for lack of a better label". His work is the most complete attempt to map out the currents of economic thought in Brazil and the place they occupied in the society. He also takes into account the "neoliberals" 6 and "socialists", who were, for the most part of the period, marginalized from the economic policy making.

Alternatively, Sola (1998, p. 52-53, 140-141), influenced by the groundbreaking definition of Jaguaribe (1962, p. 201-210), divides the "developmentalist technicians" in "nationalists" and "cosmopolitans", the latter term justified by their full acceptance of a international system hegemonized by the United Stares.

Bielschowsky's neoliberals are equivalent to the "cosmopolitan liberals" of Jaguaribe and Sola. The nationalists technicians used here, as in Sola, are presented by Jaguaribe as "developmentalist nationalists". Finally "our" market led tehonicians are the same as the "developmentalist cosmopolitans" of Jaguaribe or cosmopolitan tehcnicians of Sola. The choice of "market led" tehcnicians, instead of "cosmopolitans", will be explained in detail later. But it's our understanding that the alternative projects of development put forward by both groups of technicians implied different visions of the role of Brazil not only in the international economy but also in terms of global geopolitics. In this sense, both groups were cosmopoli-

\footnotetext{
${ }^{6}$ This category did not have at the time he wrote the book, in the eighties, the meaning it acquired later on. It was a way of describing economic liberalism in a period - the fifties and the sixties - much influenced by Keynesianism, that is, one in which the State had a role to play.
} 
tans in different ways. However, the nationalists would support a change in the "dependency relations" with the center by virtue of an "independent foreign policy".

The new categories proposed fulfill a double purpose. First, they are linked to the social positions of these groups of intellectuais interacting and also conflicting with one another within the State apparatus in order to implement their development strategies through different sets of alliances with social and political partners. The picture is dynamic as their successes and failures redefine their ideas and roles as they bring about changes in the economic and social structures. Secondly, we prefer not to use the term "developmentalist", as it was not part of their lexicon, and even more important, because it assumed later, especially after the 1990s, a connotation restricted to the realm of economics. In our view, the way "developmentalism" was more recently absorbed by the media and most of academic literature led to an impoverishment of the polissemic meaning of development (Barbosa, 2017, p. 16-50).

However, our methological approach uses this term to define the whole period - "Developmentalist Brazil" - in order to make the following point: there was a battle among different strategies of development in which these technicians in ends played a key role, as they not only mirrored but sought to sperhead the shifting allegencies of the different groups of a fast-changing society and economy. By doing so, there is an intention of questioning the almost consensual view of the literature that the political economy of the period, but also its economic policies, could be reffered to as a minimum denominator of different sorts of "developmentalisms".

Let us now move to a brief depiction of the ideas shared by each of these groups of technicians throughout the 1950s and how they unfolded in the late fifties up to 1964 once their correspondent social positions changed.

It is important to stress that the undestanding that the ideas are nurtured in the society and that some habits of though are linked to social positions comes from Karl Mannheim and his sociology of knowledge. According to Mannheim (2004, p. 35-37, 139-140, 229-233), any attempt to understand the world implies an action towards it. Every form of totalization can only be conceived if attached to the social position one belongs to. As a consequence a social rooted political thought, in the broad sense, is time and place specific and in order to become concrete it should provide an interpretation of and a guidance to historical transformation by the crafting a meaningful utopia. This utopia transcends reality in the sense that its virtual content is projected towards the future. Its supposed unachievability exists only in terms of the social order it seeks to surpass.

The nationalist technicians belonged to the larger group of State organic intellectuais, not restricted to the economists. The relationship State-people was intrinsic. Even though we do not share the view that the popular groups at the time were necessarily coopted by interests that were no theirs, as least in the view of these intellectuals and technicians, they entered in the equation as and end of a process in which their participation should be rationalized.

Their aim was the social transformation of the country, and politics a territory they were attached to from the very beninning - even though they were not politi- 
cians. The transformation should be inclusive and would not come up spontaneously. The State was seen as strategic, and economics understood as a key tool to conduct the historical process in order to complete the making of the nation with its autonomous social and political actors. They were not populists, a term also coined at the end of the period we are looking at, even though they saw its manifestation as a part of a transition process they sought to guide and put up with. Market development - with industrial diversification, increasing agriculture productivity and the creation of new links with the international economy - could lead to a modern nation, then summed up by the overcoming of "underdevelopment". In other words, national emancipation summarized their utopia, rooted in a democratic and social vision (Jaguaribe, 1962, p. 208-210; Bresser Pereira, 1968, p. 206-211).

On the other hand, the market led technicians, also settled in the core of the State, devised planning as partial and, ideally provisional, as it should pave the way for a strong private sector (Bielschowsky, 1995, p. 39-40), combining national savings - stirred by the public sector - and foreign capital, the latter seen as the most important condition for market (capitalist) development in the long term. "Populism" was understood as hampering development because inflationary economic policies were seen as increasing artificially consumption. Irrational government spending, fiscal subsidies and minimum wage increases would compromise the path towards a normal capitalist development. In their view, overcoming "underdevelopment" faced more political than economic obstacles.

So the nation meant the distribution of production factors and the size of the market, tehcnical factors or variables that filled their development equation. Thus, sound economic policies, the contention of populism and the benefits brought about by advanced and developed nations through capital and technologies would suffice to turn the country into an endogenous engine of growth. In this sense, the State role was subsumed to operate as the "liberator" of the capital accumulation potential within the country. Development was a matter of economic policy and could be measured in quantitative terms. Other structural reforms were necessary, not the ones invoked by the nationalist technicians.

The debate on development was not restricted to these technicians in ends. But the other citadels in which it was discussed - as in the case of the neoliberals controlling most of economic journals and the university courses in economics; the critical intellectuals of the academia (mostly sociologists); and the intellectuals of the popular classes - had not the same impacts in terms of decision making. One should bear in mind that BNDE was the core citadel of the State in which the technicians in ends acted. This State body to some extent mirrored the interplay of forces taking place in the society in such a way that it led to an intra-bureaucratic battle. The technicians from both sides knew each other pretty well and even belonged to the same circle of acquaintances, especially in the period 1951-1955. During JK government the conflicts arose, which did not hamper a cooperation between them at least up to 1959 (Barbosa, 2017, p. 250-251).

How can we portray the field of economic thought in the late fifties? In her 
research, Loureiro (1997, p. 18-19, 23-24, 28, 49) points out that this field was not detached from the State apparatus. Moreover, there was no such a thing as an internal homogeneity. As policy makers holding different projects these economists had not a common identity. We would say it was a fractured field. In this sense, they did not only "passed through politics", as Loureiro states, as this was the very arena in which their ideological differences were settled. Politics was much more than just a means for legitimizing their status as economists.

In fact, already by the middle of JK government, the debate changed the tone and was epitomized by two leading characters, Roberto Campos and Celso Furtado. Below we provide just a hint of their ideas in flux.

Campos (1976, p. 84-86), in a ECLAC Conference on May 1957 made a very straigthforward statement: "the dilemma of economic development, having a drammatic content and painful urgency, should prevail over social justice and political estability". In order to gain room of maneuvering, he said, it is important to establish political control over economic decision making. He stresses that the building up of "good climate for private sector investment" is more important thant "long term planning undertaken by the State". At the end, he came back to Gudin's equation: there is not development without monetary estability (Campos, 1976, p. 90-95).

At this time, Furtado was now ready to fight the battle of development in his home country, now that he carried no longer "the protector and immobilizing robe of an international employee" (Furtado, 1985, p. 200). In the lecture he gave at BNDE on September 1957, published one year later, he aimed at "determining the components of systematic policy of development" (Furtado, 2012, p. 16). According to him, not only "economic development should bring about income distribution", but also the contribution of foreign resources, although strategic in the phases of technological assimilation, should decrease once the country moves into the "superior phases of development" (p. 58-60). At the end of his essay, he stressed that to control inflation with ortodox medicines leads to capacity underutilization (p. 75-78). Confronting Campos view, he argues that "monetary estability is a fundamental, although should be subordinated to development, a more encompassing objective" (p. 79).

A polarizing configuration of the debate on development - which did not only revolve around its economic matrix but also included the social and political ends of development - ensued. More precisely in 1959, a rift was opened in the common space shared by these two kinds of economists that had evolved in spite of their differences (Kluger, 2016, p. 179). Afterwards, they followed different trajectories and filled new social positions. Their projects and views of the historical process and the political coalitions they joined could not any longer be reconciled

On the one hand, Campos left BNDE to create his own consultance company (CONSULTEC), bringing with him not only other bank cadres but also business people and professors of economics from FGV, closer to Gudin's views. According to Campos, they had in common a "capitalist rationality" (Kluger, 2016, p. 138-141, 182-183). CONSULTEC would seek to smooth the links between the private sector 
and the public bank Campos helped to create during the "Plano de Metas" (Plan of Goals).

On the other hand, Furtado started his public career in Brazil - first at SUDENE, and later on as Minister of Planning in 1963 - as a statesman intellectual that inversed the way Campos linked the realms of technical expertise and politics. The latter should not be constrained in order to let the specialists mould the economic strategy as Campos portrayed. For Furtado, technical expertise should translate and rationalize the ends posed by society into a coherent project.

As a result, the new "modernizing elites of capital" entered the scene led by Campos and his fellow private consultants and professors trying to develop new alliances within the civil society aiming to displace the populist and nationalist views; having as its counterpart Furtado, the ideal type of the statesman intellectual, as he had no choice but to mix the roles of technician and political leader, but far from becoming a traditional politician. It was the death of the technicians in ends, up until then preserved from a clear engaging with the political world. These two new social positions were nurtured in a context of potitical instability and social distress, each one trying to present their own strategies for the country's development.

The authoritarian regime sealed the process iniated 1959, erasing definitely the common space once shared by these leading characters and the social positions they represented. In april 1964, Campos became the new Planning minister and Furtado lost his political rights and was sent to a long exile.

After the coup d'état, other characters now appeared in the scene, filling in the new social positions from which economic thought was processed. The technocrats and the academic professors of economics (ortodox or heterodox as later they would be labeled) appeared in the front stage. Another character made out of the remnants of the past era was, nonetheless still alive, the interdisciplinary social scientist emerging from the shattering of the citadels of the State (once a place of dispute of deveploment ends) and of the academia (once a place in which critical thought could be produced). They were exiled from their social positions in or out of the country. This rupture made some fragments of this generation acknowledge what they had in common. An example of this was the convergence bettwen the methodological approaches of Celso Furtado and Florestan Fernandes in the seventies (Barbosa, 2018).

\section{USES OF “DEVELOPMENTALISM” IN BRAZIL AND DEVELOPMENTALIST BRAZIL AS A CONCEPT}

The methodological endeavour of this paper is informed by the semantics of historical time as conceived by Koselleck (2011, p. 97-98, 101, 104-105, 114-117, 171-179, 184-188). For the German historian, no social or economic history could be done without a correspondent history of concepts. The underlying question is the following: how did they arise and with which intention they were formulated? 
Any investigation of a concept should be connected with its "space of experience" and "horizon of expectation" which are rooted in a specific time and mobilized by the actors themselves. So is the case history itself, as any historical narrative formulates its own concepts for the "future past" it wants to bring life to.

Consequently, every historian seeks to produce a "new image of history" which is different from the stock of narratives that make up "history in general". If we agree with this perspective, the contemporary space of experience is at the core of every historical account. In short, the battle over "adequate" concepts assumes political and social relevance.

According to Koselleck, there is a tension between the concept and the "facts" they are meant to describe. The search of "adequate" concepts is therefore related to the "new theory of history" one seeks to convey. This is not a random exercise as the sources have a veto power. Moreover, a diachronic perspective should tell how events and structures get intertwined and also how some concepts are either surpassed or resist the process of change or even acquire new meanings. In some cases, as we think is ours with "developmentalism" a concept may bring about, after some structural changes take place, "decreasing returns", if we want to keep a category of economics.

In our view, the way it is mobilized by economists in the academia nowadays as a "presumed reality" of the past and the present as if nothing had changed leads to a neglect of "some structures of attitude, feeling and rhetoric" - see Said (2007, p. 82-86, 90-91) - shared by some fragments of a generation for which the concept of development (or underdevelopment) meant something else or quite different. However, as the concept is "there" as a means for establishing any conversation on what development supposedly means (and not only by economists), we present next a history of the concept "developmentalism", and its many uses, before explaining how and why we decided to reframe it.

In Chart 1 below, some authors making use of the concept "developmentalism" in order to access the ideologies and policies (mostly economic) that shaped the Brazilian development history are listed. Some of them use "developmentalism" and "national-desenvolvimentism" as synonyms while others prefer to restrict "developmentalism" to an ideology or current of thought and to classify a specific period of Brazilian history as "national-developmentalist". However, it is not often easy to find the concept clearly defined as in the case of Bielshowsky (1995) and Dutra (2014); or as in Bresser-Pereira (2014) in which the concept is rather polissemic meaning either a period, a strategy of development, a political coalition or an economic policy.

As it happens in most cases of history, the concept emerged for the first time at the end of the period it sought to describe. As coined by Jaguaribe (1962) "developmentalist nationalism" referred to an ideology of economists with a nationalst mindset filling strategic State positions. It interacts and conflicts with the "cosmopolitan developmentalism" as we already saw.

Right after, "developmentalism" became an economic strategy launched during JK government with support of the elites (especially the industrial bourgeoisie) in 
which the "nationalist" content was basically rethoric. It was an ideology, in the sense of false consciousness, that obfuscated the social contradictions faced during the industrialization as in the work of Cardoso (1972), first published in 1964, and of other sociologists from USP. Apart from its robust methodology, which amplified the understanding of the complexity of underdevelopment in Brazil, there is an underneath the surface claim that "developmentalism", hand in hand with "populism", paved the way for the 1964 rupture.

In late seventy and early eighties, a new narrative, mostly economists-driven, started to depict the period 1930-1980 as a single block. For instance, Mantega (1984, p. 64) states that the economic strategy of "national-developmentalism", inaugurated by "populist" governments of the fifties, was fully achieved during the "economic miracle" of the military regime. The devised means were implemented. But the ideology was wrong. The author loses sight of the conflicts between "our" technicians in ends and takes the whole process as motivated by the same will and strategy. As if Delfim Netto was cotinuing Furtado's job...

Fiori's view is almost the opposite. "National-develomentalism" is inherently "conservative" as it draws on ever renewed pacts, processed by and though the State, in order to satisfy the interests of different class and regional fractions (Fiori, 2003, p. 11-12, 120-123). Both narratives seem to lead to the same unescapable end, downplaying the role of history.

It deserves mentioning that the first generation of the so-called school of Campinas - meaning the Economics Department of UNICAMP - very seldom makes use of the term "developmentalism". Maria da Conceição Tavares (1998), for instance, sought to understand the role of State and the contradictions of industrialization in Brazil through its different phases and how it led to a specific pattern of capitalism development in the world periphery. The same with CEBRAP in the cases of Francisco de Oliveira and Paul Singer.

But our concept was destined to have a long life. By 1988, Bielschowsky, in the first edition of his book, defined "developmentalism" in a very precise way: "an ideology of social transformation based on a State planned project aiming at an integral industrialization" (Bielschowsky, 1995, p. 7, 247-248). Notwithstanding the very detailed and careful analysis of the economists' and intellectuals' ideas about development, the author combined the world of ideas with the historical process, as if there was not a dialetical interplay among these dimensions. In our view, the historical process, full of class contradictions, affected and "selected" some ideas, which either changed or were surpassed by it.

As we tried to show above, the JK government faced a heated internal debate between nationalist and market led technicians (mostly operating at the back stage), as the social and political conflicts were arising. These conflicts were latent up to 1959 and unfolded thereafter. So if this is usually portrayed as a period of "rising developmentalism", its demise - or the battle between development projects, as we prefer - was going on simultaneoulsy. 
Chart 1: Uses of Developmentalism in Brazil - A Historical Perspective

\begin{tabular}{|c|c|c|c|}
\hline $\begin{array}{l}\text { Year/ } \\
\text { Period }\end{array}$ & Concept & $\begin{array}{c}\text { Author/Current of } \\
\text { Thought }\end{array}$ & Interpretation \\
\hline 1962 & $\begin{array}{l}\text { "Developmentalist } \\
\text { Nacionalism" }\end{array}$ & $\begin{array}{l}\text { Helio Jaguaribe and } \\
\text { Bresser-Pereira (1968) }\end{array}$ & $\begin{array}{l}\text { Ideology hold by some public sector } \\
\text { economists with a nationalist frame } \\
\text { of mind. }\end{array}$ \\
\hline $\begin{array}{l}\text { 1960s and } \\
1970 \text { s }\end{array}$ & $\begin{array}{l}\text { "Nacional-Developmentalism" } \\
\text { or "Developmentalism" } \\
\text { (JK government) }\end{array}$ & $\begin{array}{l}\text { Sociological School } \\
\text { of USP (Fernando } \\
\text { Henrique Cardoso } \\
\text { and others) }\end{array}$ & $\begin{array}{l}\text { Critical to ISEB and the nationalist } \\
\text { technicians. Analysis focusing on class } \\
\text { relations and stressing how industrial } \\
\text { business were aligned to oligarchic } \\
\text { groups. The former group benefits from } \\
\text { State conservative intervention and } \\
\text { also from the connections stablished } \\
\text { with foreign capital. Developmentalism } \\
\text { is an economic strategy aimed to } \\
\text { disguise vested class interests and as } \\
\text { such takes advantage of "populism". }\end{array}$ \\
\hline $1980 \mathrm{~s}$ & $\begin{array}{l}\text { "Nacional - } \\
\text { Developmentalism" (period } \\
\text { 1930-1980) }\end{array}$ & $\begin{array}{l}\text { Guido Mantega and } \\
\text { José Luis Fiori }\end{array}$ & $\begin{array}{l}\text { The period 1930-1980 is seen as block. } \\
\text { For Mantega, the military regime is } \\
\text { a continuation of developmentalist } \\
\text { economic policies of the fifties. } \\
\text { Fiori's critical view stress that the } \\
\text { State has been captured over the } \\
\text { period by the political and economic } \\
\text { elites in order to promote "escapes } \\
\text { forward" and remove any attempt } \\
\text { towards democracy and redistribution. } \\
\text { Developmentalism is conservative. }\end{array}$ \\
\hline 1990s & $\begin{array}{l}\text { "Nacional - } \\
\text { Developmentalism" (period } \\
\text { 1930-1980) with negative } \\
\text { signal }\end{array}$ & $\begin{array}{l}\text { Gustavo Franco and } \\
\text { the new neoliberals }\end{array}$ & $\begin{array}{l}\text { State intervention and industrialization } \\
\text { process are doomed as inflationary, } \\
\text { self-sufficient and responsible for } \\
\text { inequality. National-developmentalism } \\
\text { as failure, a model to be overcome. }\end{array}$ \\
\hline Years 2000 & $\begin{array}{l}\text { "Nacional - } \\
\text { Developmentalism" (period } \\
\text { 1930-1980) with positive } \\
\text { signal }\end{array}$ & $\begin{array}{l}\text { Bresser-Pereira and } \\
\text { most heterodox } \\
\text { economists }\end{array}$ & $\begin{array}{l}\text { The period is seen as one in which the } \\
\text { country faced important } \\
\text { transformations in the production } \\
\text { structure led by State planning. } \\
\text { However, it is combined with growing } \\
\text { inequality and internalization of } \\
\text { dependency, increased during the } \\
\text { military regime. It is not any longer } \\
\text { replicable. }\end{array}$ \\
\hline $\begin{array}{l}\text { Lula and Dilma } \\
\text { Governments }\end{array}$ & $\begin{array}{l}\text { "New Developmentalism" X } \\
\text { "Social - Developmentalism" }\end{array}$ & & $\begin{array}{l}\text { The new developmentalists (led by } \\
\text { Bresser-Pereira) argue againt fiscal and } \\
\text { exchange-rate" populism", whereas } \\
\text { social-desenvolvimentists stress the } \\
\text { gains in terms of social inclusion and } \\
\text { inequality reduction, leading to the } \\
\text { fostering of the internal market and } \\
\text { public spending in infrastructure. This } \\
\text { view is shared by some heterodox } \\
\text { economists. }\end{array}$ \\
\hline
\end{tabular}




\begin{tabular}{|l|l|l|l|}
\hline $\begin{array}{l}\text { Years } 1980 \\
\text { (academic } \\
\text { literature) }\end{array}$ & "Developmentalism" & $\begin{array}{l}\text { As shown before, these interpretations } \\
\text { highlight the differences and similarities } \\
\text { of the the main currents of though of } \\
\text { "developmentalists" and technicians } \\
\text { devising tools and concepts in order to } \\
\text { understand/orient the industrialization } \\
\text { process. In Bielshowsky, } \\
\text { "developmentalism" belongs to the } \\
\text { material world (with its own } \\
\text { periodization) and also to the world } \\
\text { of ideas. }\end{array}$ \\
\hline $\begin{array}{l}\text { 1990s and } \\
\text { years 2000 }\end{array}$ & "Developmentalism" \\
(academic \\
literature)
\end{tabular}

Source: Author's elaboration. The author's cited in the chart are discussed in the paper.

The "national-developmentalism" became also part of the lexicon of the new neoliberals ${ }^{7}$. They turned the concept on its head in order to provide a deceiving narrative of the "future past". This surgery was essential for their attempt to inaugurate a new model of development. As it had been transformed into a block covering the period 1930 to 1980, it was just a matter of inverting the signal. The economic strategy that predominated over the entire period could be summed up in three terms: inflation, State intervention (impairing productivity) and self-sufficiency (Franco, 1999, p. 68-70).

However, as the limits of the supposedly new model, one which supposedly the Real Plan would give birth to, led to a crisis in the late nineties, the hererodox economists narrative came back in the years 2000 with a more positive account of the period 1930-1980, as now it could be compared to what "neoliberalism" had actually delivered.

Bresser-Pereira (2016, p. 10, 15-21, 30-31), for instance, conveys the following narrative: the building of capitalism and of the nation were convergent over the period 1930-1980 through different political coalitions and mixes of economic policies. There were limits and obstacles, but they could be overcome by a new strategy of economic development, labelled as "new developmentalist".

The aim of this paper is not to discuss in detail this economic strategy and its internal coherence or applicability. But it is important to acknowledge that it emerged initially as criticism of both the "old developmentalism" and some of the aspects re-

\footnotetext{
7 The "new neoliberals" are made of Gudin's descendants. But now they face a country already industrialized and with a powerful State they cannot get rid of easily. Monetary stability and productivity are components of the new discourse as in Gudin's, but there is a need to update the overall analysis of the Brazilian economy.
} 
lated to Lula's economic policy. Just like what was called "social-developmentalism" intended to describe and consolidate the narrative that the PT-led government managed to combine growth with social inclusion, inaugurating a new development model ${ }^{8}$.

For our purpose, it is important to acknowledge that the concept of "developmentalism" or "national-developmentalism", in most of the cases, was caught from history devoid of the historical context that nurtured the practice and debate on development. Most of the debate held between the new neoliberals, new developmentalists, social-developmentalist and by the new market-let economists was framed in such a way that they primarily absorbed the new theories from their international counterparts and, as a second step, applied them to the Brazilian economy.

Most economists are neither connected to the wider society, nor seek to incorporate the diverse societal views into a coherent direction, which would require both a critical diagnosis of the social, economic and political changes in the long term and the building of new projects and utopias. The autonomy of the economic science was finally reached as the new citadels of economic thought - the economic departments - arise in the surface proud of their own knowledge.

Even the technocrats, a figure created in post-1964 era - the specialist in means that would meet the ends posed by the authoritarian government - had changed. Most of them, especially in the case of the new neoliberals, had become part-time technocrats as they had their businesses to take care of.

The post-2010 debate revolved around the criticisms the new neoliberals addressed to social-developmentalists for bringing back the "national-developmentalist" model during the second Lula government and the Dilma period, as if history could come over again. On the other hand, social-developmentalists tried to defend the successful movement forward during the years 2000, while new developmentalists posed serious criticisms to the economy policy implemented in the years 2000 and over.

The lack of a common definition, and the use of "developmentalism" especially by the new neoliberals as synonym to interventionism, has brought back the debate of whether and how the concept can be updated in order to describe and change the new reality. According to Fonseca (2016, p. 117-119, 125-127), there are three reasons for using the concept today. The first is utilitarian: everyone needs it for having a conversation, no matter how diverse are the definitions. The second is historical: the meaning of concepts change with history. Finally, there is a material reason: whenever there is underdevelopment, there will be a consciousness devoted to its overcoming. This last point deserves as article in itself: if the reality of underdevelopment is there in a new fashion in contemporary Brazil, the answer to how underdevelopment can be assessed today through a historical-structural approach seems to be lost in the past or confined to a small group of economic historians and social scientists.

The above discussion is only a broad account of the present debate - which is surely more complex and nuanced - as seen by the lens of an economic historian who spent the last years as a researcher immersed in an historical period in order to make

\footnotetext{
${ }^{8}$ For a discussion on the main tenets and limits of both the new developmentalism and socialdevelopmentalism, see Bastos (2012, p. 784-800).
} 
sense of the complexities, ruptures and continuities of the development process and practice in Brazil. The attempt was to show how economic thought has become detached of development as a project-interpretation-utopia of transforming society toward projected ends seemingly viable. The precondition for an attitudinal transformation of the field is an interpretation that allows for an understanding of the structural changes the Brazilian capitalist economy - intertwined with the social and political dimensions and the world of ideas - has gone through after the 1980 .

This methodological procedure oriented our conceptualization of Developmentalist Brazil for the period 1945-1964. It brings a partial rupture with the period 1930-1945, one that created the base for a capitalist national State, but in which the societal alternatives were blocked by its authoritarian and centralized nature.

After the 1946 Constitution and the opening up of the political arena to parties and social movements - with the exception of Communist Party of Brazil (PCB), proscribed in 1947 -, intellectuals and technicians started to act both in the political society and in the civil society. The Sate became a strategic space of dispute between alternative projects that evolved aligned with economic and political changes. New social positions within the State tried to direct the development process once controlled by traditional political elites, while new actors were brought to the central stage as transnational companies and State enterprises. Industrialization set the ground for the rising of a national bourgeoisie and a fast growing urban working class.

Development then emerged as a means to incorporate technology, increase productivity and create jobs, and also change the trade patterns. The idea that this process would be spontaneous and that the State should not play a role in the industrialization lost appeal in the early fifties. Development also meant, especially for the State organic intellectuals, health and education policies, social security universalization, agrarian reform and an independent foreign policy. A process of social transformation was required to overcome underdevelopment, and the growing and diversifying economy was seen as a means, not as an end in itself. Democracy was also essential, not a byproduct of development. The writings of Rômulo Almeida in the early fifties and of Furtado at the turn of the sixties are very straightforward in this respect.

But the battle over development was not one of ideas only. They were used and set aside depending on the power structure and the different political coalitions more suitable to the elites and powerful class interests, which also changed in the meantime. Moreover, mass politics filled the scene. The technicians in ends - nationalists and market led - interacted and conflicted with each other within the State but also tried to reach out to different social groups, which played a role in their alternative projects of development. The social groups were also very dynamic in terms of the power they had and the ideologies they shared.

So, development was the main issue, even though it conveyed different meanings. The nationalist technicians - a segment of the larger group of the State organic intellectuals - were well positioned at least up to 1954 and tried to set up alliances with social movements, and segments of private capital, but their ties were weaker outside of the State. On the other hand, market led technicians were located in the strategic places in which the State met with the private capital (both national and transnational companies) interests. Also, the latter was more prone to satisfy the traditional 
elites' demands. During JK government, this picture was already clear. The market led technicians left the government asking for inflation control and criticizing the government rupture with the IMF. They decided the transfer the battle to the civil society, by gathering support of capitalist groups.

In the early sixties, especially during João Goulart government, the need to interact with a more fragmented and polarized society, weakened the role of the State organic intellectuals and opened the space for technicians playing a political role (statesman intellectuals). However, the possibility of reaching a broad agreement in a context of more autonomous social movements - now already criticizing both "developmentalism" and "populism" - was severely constrained. Market led technicians offered a safe avenue for the entrenched elites. They behaved as modernizing elites of capital to which they spoke out. The conquest of the political society was the next step in order to normalize the capital accumulation process now free from what was conveyed as "premature distribution". They also pictured themselves as having the tools for a "self-sustained growth" with no pressures from below and a new alliance with the "Western world".

Following this narrative ${ }^{9}$ which connects social positions and ideas and how they were twisted in favour of a new historical block that benefited from the internationalization of the Brazilian economy and the closure of the State to counter elites and popular classes, helps to unveil the process of how an alternative developmental project-interpretation-utopia who sought to lead the process of change lost ground. The State organic intellectuals were never hegemonic as their ties with the societal forces pushing for an "autonomous development" were increasingly loosened. They also failed to advance a "political economy of reforms" that differentiated short term and long-term goals in order to bring about political support for each of them.

The emergence of the technocrat was the signal of new political culture and of new relations between State and capital accumulation. The country entered the post-developmentalist period (1964-1980) $)^{10}$, in which the idea of nation was devoid of any substantial meaning apart from the ideology of economic growth that would lift everyone. Underdevelopment was lost in the past. The State itself was a fortress of the allied capitalist interests, opened to different forms of clientelism. No project of class composition, just the class content of a regime proud of its hegemonic power without consent.

The contradictions of Developmentalist Brazil and the way they were finally settled paved the way for the view that development was equivalent to the expansion of productive forces which nonetheless would pose new threats to the continuity of the new regime. Underdevelopment became more entangled and, most importantly, lost power as an interpretation, and the project and utopia that were associated with

\footnotetext{
${ }^{9}$ The main idea is to provide a methodology of historical analysis in which the totality of the interconnected events and structures does not jeopardize the fluidity of the process and its main alternatives. See Mannheim, 2004, p. 237-238.

${ }^{10}$ In this specific aspect we depart from the important works of Sola (1998), Bielschowsky \& Mussi (2005), Fonseca (2014) and Bresser-Pereira (2014), as they consider the post-1964 period as "developmentalist".
} 
it from the very beginning were buried from history, at least in most of the narratives produced by economists and social scientists.

\section{FINAL REMARKS: HISTORICIZING AND (RE)PERIODIZING DEVELOPMENT IN BRAZIL AS A RESEARCH PROGRAMME}

As pointed out by Le Goff (2015, p. 12), “every periodization means a human action towards time", so the final cutting is never neutral. Our methodological choice - rather than extending the concept by creating subtypes of "developmentalism", as proposed by Fonseca (2014, p. 32-36), was to look at a specific period more intensively. That is, to open its black box and show the contradictions between ideas and social positions, on the one hand, and the structural processes that led to a change in the political and economic structures of capitalism on the other.

In our view, as development projects or perspectives are always disputed, and this dispute matters, we lose a great deal of history by selecting common denominators that would enable to describe a government or an economic policy as "developmentalists". The policies and governments are made out of conflicts between social actors and the ideas and positions they hold in the structure of power in such a way that none of them fully prevail. Development is therefore neither a simple result nor is restricted to the realm of economic policies, as the social and political dimensions "select" the ideas and condition the economic policy making.

If the structure of power, the changes in social stratification, the patterns of integration in the capitalist world-economy, the relations between the State and the private sector, and even the social positions from which development is conceived, changed so dramatically, then we should ask: is it still meaningful to use today the concept of "developmentalism", which suggests continuity with the past?

In case our approach is robust, we can put forth a research programme that allows for extending the methodological approach applied for the period 1945-1964 up to the contemporary period. In order to accomplish this task, it is key to understand the dialectical movement between the world of ideas and the material world, the latter including the social and political dimensions as intertwined with the changing economic structures both in terms of the "national economy" and of its relations with the more recent transformations of the capitalist world-economy. An alternative periodization could also bring new light to the dilemmas faced in the post-1980 period.

This is just a sketch of a possible research programme: one that would transcend the presumed reality and unveil some underlying structural dynamics that affect the different governments of the period, presenting their inner contradictions, the way they evolved and whether and how the world of ideas - pushed by specific social actors - was able to intervene in the process of change. Only then a portrait of the contradictions of capitalism in Brazil in the long term would come about by bringing together the wider structures and how the social and political actors, and the intellectuals of different kinds, were able to convey ideas both as interpretations and guiders of the process. 
To sum up, can the variety of capitalism established in Brazil after the crisis of the post-developmentalist period in the eighties give birth to a critical account (interpretation) of the process as it unfolded in the following forty years? Can a new set of developmental ideas flourish? Which social actors would embrace them? An understanding of how the capitalist structures of accumulation have been connected and subordinated to the capitalist world-economy and how it impacted the social stratification seems to be a precondition for forging a new project and utopia. The new project-interpretation-utopia - if it is still conceivable to rejuvenate this triad for the world we live in - will not be bestowed upon new counter-hegemonic forces, but probably nurtured within them.

In times of crisis, to think big and humble is a necessity. Our time begs a "constructed history", instead of the much praised "additive history", as the task is to "brush history against the grain", not to follow the "triumphal procession of the winners" as summed up magnificently by Walter Benjamin (apud Löwy, 2005, p. 70, 123, 130).

\section{REFERENCES}

ALMEIDA, Rômulo. (1950) “Carta dirigida ao Dr. Landulpho Alves, presidente do diretório do PTB na Bahia”, 5 ago. 1950. Acervo IRAE.

BARBOSA, Alexandre de Freitas.(2017) O Brasil Desenvolvimentista (1946-1964) e a trajetória de Rômulo Almeida: ensaio de interpretação histórica. 636. Tese (Livre Docência em Histórica Econômica). IEB/USP, São Paulo.

BARBOSA, Alexandre de Freitas.(2018) "Interpretando o fim do ciclo 1988-2016: pode a "parceria" Furtado e Florestan fornecer novas pistas teóricas e metodológicas para entender o presente passado?”. In 42o Encontro Anual da ANPOCS (GT31 - Teoria Política e Pensamento Político Brasileiro - Conflito, poder, legitimidade e Estado). Caxambu, outubro 2018.

BASTOS, Pedro Paulo Zahluth. (2012) "A economia política do novo-desenvolvimentismo e do social-desenvolvimentismo". In: Economia e Sociedade, número especial (Desenvolvimento e desenvolvimentismo(s) no Brasil), dez. 2012.

BIELSCHOWSKY, Ricardo.(1995) Pensamento econômico brasileiro: o ciclo ideológico do Desenvolvimentismo. $2^{\text {a }}$ edição. Rio de Janeiro: Contraponto, 1995.

BIELSCHOWSKY, Ricardo e MUSSI, Carlos (2005) O Pensamento desenvolvimentista no Brasil: 19301964 e anotações sobre 1964-2005, mimeo, julho de 2005.

BRANDÃO, Gildo Marçal.(2007) Linhagens do Pensamento Político Brasileiro. São Paulo: Aderaldo \& Rothschild Editores.

BRESSER-PEREIRA, Luiz Carlos. (2016) A construção política do Brasil: Sociedade, Economia e Estado desde a Independência. $3^{a}$ edição. São Paulo: Editora 34.

BRESSER-PEREIRA, Luiz Carlos (1968) Desenvolvimento e crise no Brasil: entre 1930 e 1967. Rio de Janeiro: Zahar Editores.

CAMPOS, Roberto. (1976) Ensaios de História Econômica e Sociologia. 3a edição. Rio de Janeiro: APEC Editora.

CAMPOS, Roberto. (1994) A lanterna na Popa: memórias. Rio de Janeiro: Topbooks.

CARDOSO, Fernando Henrique. (1972) Empresário industrial e desenvolvimento econômico no Brasil. $2^{a}$. edição. São Paulo: Difel.

CUNHA, Mário Wagner Vieira (1963) . O sistema administrativo brasileiro, 1930-1950. Rio de Janeiro: INEP.

D’ARAÚJO, Maria Celina Soares. (1992) O Segundo Governo Vargas 1951-1954: democracia, partidos e crise política. $2^{\text {a }}$ edição. São Paulo: Ática.

DRAIBE, Sônia. (1985) Rumos e metamorfoses. Rio de Janeiro: Paz e Terra. 
FIORI, José Luís. (2003) O voo da coruja: para reler o desenvolvimentismo brasileiro. Rio de Janeiro: Record.

FONSECA, Pedro Cezar Dutra. (2014) "Desenvolvimentismo: A Construção do Conceito". In: Presente e futuro do desenvolvimento brasileiro, CALIXTRE, André Bojikian, BIANCARELLI, André Martins e CINTRA, Marcos Antonio Macedo (orgs.). Brasília: IPEA.

FONSECA, Pedro Cezar Dutra. (2016) "O projeto desenvolvimentista no Brasil: histórico e desafios da atualidade”. In: Cadernos do Desenvolvimento, Vol. 11, n. 19, julho-dezembro. Rio de Janeiro: CICEF.

FRANCO, Gustavo. (1999) O desafio brasileiro: ensaios sobre Desenvolvimento, Globalização e Moeda. São Paulo: Editora 34.

FURTADO, Celso. (1985) A fantasia organizada. 5a edição. Rio de Janeiro: Paz \& Terra.

FURTADO, Celso. (2012) Perspectivas da economia brasileira. Rio de Janeiro: Centro Internacional Celso Furtado de Políticas para o Desenvolvimento.

LE GOFF, Jacques. (2015) A História pode ser dividida em pedaços? São Paulo, Editora Unesp.

GRAMSCI, Antonio. (2017) Cadernos do Cárcere: Os Intelectuais. O Princípio Educativo. Jornalismo Vol. 2. $8^{a}$ edição. Rio de Janeiro: Civilização Brasileira.

GRAMSCI, Antonio. (2011) Cadernos do Cárcere: Maquiavel - Notas sobre o Estado e a política - Vol. 3. $3^{a}$ edição. Rio de Janeiro: Civilização Brasileira.

GUERREIRO RAMOS, Alberto. (1995) “Entrevista”. In: OLIVEIRA, Lucia Lippi. Sociologia do Guerreiro. Rio de Janeiro: Editora da UFRJ.

JAGUARIBE, Hélio. (1958) Condições institucionais do desenvolvimento. Rio de Janeiro: ISEB.

JAGUARIBE, Hélio. (1962) Desenvolvimento econômico e desenvolvimento político. Rio de Janeiro: Fundo de Cultura.

KLÜGER, Elisa. (2017) Meritocracia de laços: gênese e reconfigurações do espaço dos economistas no Brasil. Tese (Doutorado em Sociologia). Faculdade de Filosofia, Letras e Ciências Humanas, Universidade de São Paulo, São Paulo.

KOSELLECK, Reinhart. (2006) Futuro Passado: Contribuição à semântica dos tempos históricos. Rio de Janeiro: Contraponto/Editora PUC Rio.

LAFER, Celso. (2002) JK e o Programa de Meta (1956-1961): processo de planejamento e sistema político no Brasil. Rio de Janeiro: Editora FGV.

LOUREIRO, Maria Rita. (1997) Os economistas no Governo: gestão econômica e democracia. Rio de Janeiro: Editora FGV.

LÖWY, Michel. (2005) Walter Benjamin: aviso de incêndio - uma leitura das teses sobre o conceito de História. São Paulo: Boitempo.

MANNHEIM, Karl. (2004) Ideología y utopia: introducción a la Sociología del Conocimiento. Edición Comemorativa de 70 Años. Cidade do México: Fondo de Cultura Económica.

MANTEGA, Guido. (1984) Economia política brasileira. 2a Edição. São Paulo: Vozes.

MARTINS, Luciano. (1976) Pouvoir et développement économique: formation et évolution des structures politiques au Brésil. Paris: Éditions Anthropos.

MICELI, Sergio. (2012) Intelectuais à brasileira. São Paulo: Companhia das Letras.

PÉCAUT, Daniel. (1990) Os intelectuais e a política no Brasil: entre o povo e a nação. São Paulo: Ática

SAID, Edward. (2007) Humanismo e Crítica Democrática. São Paulo: Companhia das Letras.

SIMONSEN, Roberto e GUDIN, Eugênio. (2010) A controvérsia do planejamento na economia brasileira. $3^{\text {a }}$ edição. Brasília: IPEA.

SOLA, Lourdes. (1998) Ideias econômicas, decisões políticas. São Paulo: EDUSP.

TAVARES, Maria da Conceição. (1998) Acumulação de capital e industrialização no Brasil. $3^{a}$ edição. Campinas: IE/UNICAMP.

VARGAS, Getúlio. (1951) Mensagem ao Congresso Nacional: apresentação pelo Presidente da República por ocasião da abertura da Sessão Legislativa de 1951. Rio de Janeiro: Departamento de Imprensa Nacional. 